\section{PERMASALAHAN PELESTARIAN SUMBER DAYA AIR JAKARTA}

Oleh: Tri Nugraha Adikesuma

Universitas Pembangunan Jaya, sakaraka00@gmail.com

\section{Abstrak}

Air adalah materi vital bagi setiap makhluk hidup. Namun keberadaannya seringkali tidak disyukuri dan disia-siakan dan disalahgunakan. Pengelolaan air yang tidak pada tempatnya ini menyebabkan munculnya begitu banyak kerugian. Pelestariannya yang diabaikan menyebabkan permasalahan ketika jumlah air melimpah pada musim penghujan, namun tidak bisa dimanfaatkan. Ketika musim kemarau tiba, jumlahnya tidak seberapa, dan untuk mendapatkannya memerlukan pengorbanan lebih. Jakarta adalah salah satu kota di dunia yang mengalami permasalahan serupa. Volume air yang melimpah di musim penghujan menyebabkan banjir di manamana, menimbulkan kerugian yang tidak sedikit dalam berbagai aspek. Di musim kemarau, banyak anggota masyarakat yang kesulitan mendapatkan air untuk memenuhi kebutuhan sehari-hari.

Kajian ini dibuat untuk mengidentifikasi permasalahan pengelolaan air Daerah Khusus Ibukota Jakarta dari sudut pandang konservasi Sumber Daya Air. Permasalahan penggunaan tanpa izin kawasan bantaran sungai dan perubahan tata guna lahan di berbagai bagian Daerah Aliran Sungai, terutama di bagian hulu menjadi masalah yang tidak bisa dibiarkan begitu saja. Peningkatan angkutan sedimen karena erosi lahan dan penurunan indeks kualitas air juga patut mendapatkan perhatian lebih.

Kata kunci: Air, Konservasi, Jakarta

\section{Abstract}

Water is a vital matter for every living thing. Despite that, more than often, its presence doesn't get any appreciation, wasted, and misused. This misplaced water management gives birth to so many losses. Neglected effort in conserving water causes problem in the rainy season. Abundant water flowing everywhere, but cannot be used. When the dry season comes, the quantity of water available diminished, and to get some, extra sacrifices are going to be needed. Jakarta is one of the city in the world that facing similar problems. Abundant volume of water in rainy season causes flood everywhere, causing massive loss in various aspects. In dry season, lots of people having difficulties to access water to fulfil their daily needs.

This study was made to identify problems within water management in Special Capital Region of Jakarta from water resources conservation point of view. Problems on unauthorized using of river banks and the changes of land use on various area in the 
catchment area, especially in the mainstream, become problems that can no longer be tolerated. The increased volume of sediment transport because of land erosion and the decreasing value of water quality index should also get more attention.

Keywords: Water, Conservation, Jakarta

\section{PENDAHULUAN}

\subsection{Latar Belakang}

Air merupakan kebutuhan vital bagi setiap makhluk hidup. Keberadaannya menjadi awal dari munculnya kehidupan. Keberadaannya ini menjadi anugerah yang perlu disyukuri dan diapresiasi bukan disiasiakan apalagi disalahgunakan.

Cara manusia mensyukuri dan mengapresiasi sewajarnya dilakukan dengan menata air lebih baik. Untuk bisa menata air dengan baik, perlu disadari hakikat dan sifat-sifat air. Penataan air yang tidak baik akan mendatangkan permasalahan. Permasalahan-permasalahan yang timbul, tidak jarang diperlakukan sebagai bencana karena mempengaruhi begitu banyak manusia pada wilayah yang luas. Hanya manusia yang bisa merekayasa anugerah dan masalah ini.

\subsection{Rumusan Masalah}

Kajian untuk mengatasi permasalahan air DKI Jakarta telah banyak dilakukan, dengan isu yang dibahas tidak terbatas pada pengendalian air dari hulu ke hilir. Ketika berbicara tentang pengelolaan air, kita tidak akan bisa melepasnya dari permasalahan pengelolaan lahan. Alih fungsi pada bagian hulu Daerah Aliran Sungai telah mengurangi kemampuan tanah untuk menahan air. Perubahan koefisien pengaliran lahan menjadi lebih besar menyebabkan naiknya debit aliran permukaan. Perubahan alih fungsi lahan ini tidak akan lepas dari kepentingan ekonomi yang seringkali berseberangan dengan tujuan penataan air.

Pengambilan air tanah secara berlebihan tidak lagi bisa dipantau dengan baik oleh pemerintah. Perundang-undangan dan perizinan seringkali tidak diindahkan demi pemenuhan kepentingan sebagian kecil anggota masyarakat. Penurunan muka air tanah Jakarta terjadi setiap tahunnya, meningkatkan laju masuknya air laut ke daratan.

Laju penurunan elevasi tanah DKI Jakarta menambah rumit permasalahan pengelolaan air di kawasan yang berada di dalam Daerah Pengaliran Sungai Ciliwung ini. Penurunan permukaan tanah DKI Jakarta setiap tahun dan kenaikan permukaan air laut menambah sulitnya penyaluran air dari daratan ke laut. Ada begitu banyak penyebab banjir, namun munculnya penyebab-penyebab banjir tersebut merupakan kegagalan manusia mengelola air dengan baik.Semua faktor itu 
jarang dikaji secara menyeluruh, yang mengakibatkan penyelesaian permasalahan air tidak pernah berujung pada sebuah akhir yang jelas.

\subsection{Tujuan Kajian}

Kajian ini dibuat sebagai bagian dari studi manajemen resiko Pengelolaan Sumber Daya Air Daerah Khusus Ibu Kota Jakarta. Sasaran akhir kajian ini adalah penyediaan identifikasi permasalahan-permasalahan Pengelolaan Sumber Daya Air dari sudut pandang Pelestarian Air yang muncul pada Daerah Aliran Sungai Ciliwung - Cisadane sebagai dasar untuk studi selanjutnya.

\subsection{Metode Pelaksanaan Kajian}

Kajian ini dibuat dengan pendekatan kajian meja. Dengan memanfaatkan laporanlaporan, Master Plan pengembangan wilayah Daerah Aliran Sungai Ciliwung Cisadane, dibuat sintesis masalah dengan menyandingkannya dengan studi-studi dan peraturan yang telah dibuat terkait pengembangan wilayah Daerah Aliran Sungai tersebut.

\section{TINJAUAN TEORITIS}

\subsection{Sejarah Permasalahan Air Jakarta}

Jakarta, sebagai Ibu Kota Negara Republik Indonesia telah lama merasakan dampak dari kurangnya penataan air yang baik. Banjir di Jakarta telah terjadi di wilayah
Jakarta sejak Jakarta didirikan di atas kota pelabuhan Kalapa pada tahun 1619 dan masih bernama Batavia. Pada masa itu, kanal-kanal mulai dibangun untuk mengatasi permasalahan banjir. Namun pada tahun 1633, dilaporkan kanal yang terbangun mengalami kekeringan dan menyebarkan bau tak sedap. Pada tahun 1665, dilaporkan elevasi air terkadang naik lebih tinggi dari kota, dan pada 1670 banjir rob menggenangi jalan-jalan di Batavia.

Pada tahun 1922, De Haan membuat laporan yang menyebutkan penyebab, efek dan solusi banjir yang terjadi di kota Batavia. Di antara penyebab-penyebab tersebut, dinyatakan penebangan pohon di hulu Sungai Ciliwung telah menyebabkan naiknya muka air di sungai dan meningkatkan depot sedimen larian dalam sungai. Runtuhnya tebing-tebing pembatas sungai juga menyebabkan naiknya kadar angkutan sedimen dalam air sungai. Faktor lain yang menyebabkan sulitnya air di Jakarta diatur adalah distribusi air ke area sawah yang diperluas.

Sethuraman menyampaikan evaluasinya tentang banjir Jakarta dalam berkas Master plan Jakarta tahun 1965 - 1985. Dalam berkas ini, disebutkan permasalahanpermasalahan sungai di Jakarta. Permasalahan-permasalahan yang muncul diawali dengan kekurangan efektifitas hampir semua sungai yang mengalir 
melewati Jakarta. Pendangkalan sungai karena pembuangan limbah padat langsung ke badan sungai terjadi di hampir semua sungai dan saluran drainase. Muara sungai juga mengalami pendangkalan karena proses pengendapan sedimen yang terbawa dari hulu. Belum lagi ditambah dengan rusaknya konstruksi infrastruktur-infrastruktur air. Pada tahun 1965 ini pula sebuah proyek jangka panjang untuk membangun jaringan saluran drainase dan sistem reservoir dimulai.

Upaya penanggulangan banjir ini kemudian dilanjutkan dengan pengajuan pembangunan kanal banjir timur pada tahun 70-an oleh NEDECO (Netherlands Engineering Consultants). Perencanaan kanal banjir timur ini pada 1990 dikembangkan kembali bekerjasama dengan JICA (Japan International Cooperation Agency). Dan pada awalnya direncanakan selesai dibangun pada tahun 2010 .

Pada saat ini pula, muncul konsep pengembangan Pantai Utara (Pantura) karena permasalahan air bersih yang disebabkan oleh pengambilan air tanah berlebihan. Permasalahan ini juga yang menyebabkan munculnya pernyataan yang mengatakan pengembangan Jakarta tidak bisa dilakukan ke Selatan, melainkan ke Timur dan Barat.
Pada tahun 1984, Master plan Jakarta untuk periode kerja 1985 - 2005 menyebutkan rencana pengaturan banjir dan drainase wilayah. Pada berkas Master Plan ini disebutkan mengenai pengaturan banjir dan drainase. Pada master plan ini sistem pengatur banjir dibagi ke dalam tiga bagian, yaitu bagian tengah, bagian timur, dan bagian barat. Pada bagian tengah, ditekankan pembangunan Waduk Depok dan peningkatan sistem polder yang telah ada. Di wilayah barat, penyelesaian kanal banjir Cengkareng diprioritaskan. Di bagian timur, penyelesaian pembangunan bagian hulu kanal banjir timur direncanakan selesai pada tahun 2005. Selain pembangunan Waduk Depok dan penggunaan danau buatan, prioritas lain yang disebutkan dalam berkas ini adalah peningkatan koordinasi antar instansi yang bertugas menjaga pembatasan pembangunan perkotaan di bagian selatan Jakarta, dan kebersihan sungai dari sampah, limbah rumah tangga, limbah industri.

Berkaca dari banjir besar yang terjadi pada tahun 2007, pada tahun 2008, Firdaus Ali mengemukakan gagasannya tentang Multi Purpose Deep Tunnel (MPDT) pada acara Singapore International Water Week. Terowongan bawah tanah ini didesain sebagai terowongan pengontrol banjir, sekaligus sebagai pengantar air bersih dan air buangan, juga sebagai terowongan jalan, dan jalur utilitas kota. 
Pada tahun 2014, dikeluarkan sebuah Draft Master Plan untuk pembangunan kawasan pesisir terpadu. Dalam dokumen ini, disebutkan rencana pembangunan tanggul laut di lepas pantai Jakarta. Tanggul laut yang kemudian dikenal dengan sebutan Jakarta Giant Sea Wall. Tanggul laut ini direncanakan sebagai upaya terpadu untuk mengatasi permasalahan air Jakarta.

\subsection{Rencana Tata Ruang Wilayah}

Sebagai upaya untuk mengoptimalkan pengaturan pengelolaan wilayah, dikeluarkan beberapa arahan sebagai panduan penataan wilayah. Di dalam peraturan ini terdapat arahan pengendalian pemanfaatan ruang, penetapan lokasi dan fungsi ruang untuk investasi, penataan kawasan strategis nasional, pemanfaatan sumber daya alam, dan pelestarian lingkungan hidup. Berikut dipaparkan batasan-batasan pengelolaan wilayah yang termasuk di dalam Daerah Aliran Sungai 2 Ci (Ciliwung, Cisadane) yang langsung berhubungan dengan Daerah Khusus Ibukota Jakarta.

\subsection{Arahan Struktur Pemanfaatan}

\section{Ruang/ Rencana Struktur Ruang wilayah}

Menurut Peraturan Pemerintah Nomor 26 Tahun 2008 tentang Rencana Tata Ruang Wilayah (RTRW) Nasional dan berdasarkan Rencana Tata Ruang (RTR) Pulau, arahan struktur pemanfaatan ruang/rencana struktur ruang wilayah di WS 2 Ci dibagi menjadi:

\subsection{Kawasan Strategis Nasional (KSN)}

Dalam RTRW Nasional dan RTRW Pulau Jawa dan Bali ditetapkan 2 (dua) KSN. Salah satu KSN yang dimaksud berada dalam Wilayah Sungai $2 \mathrm{Ci}$, yaitu Kawasan Perkotaan Jabodetabekpunjur (Metropolitan Jabodetabekpunjur)

\subsection{Kawasan Andalan}

Dalam RTRW Nasional dan RTRW Pulau Jawa dan Bali, Wilayah Sungai $2 \mathrm{Ci}$ ditetapkan sebagai wilayah pengelolaan Wilayah Sungai lintas provinsi (lihat Peraturan Pemerintah nomor 26 Tahun 2008 lampiran VI dan Peraturan Menteri Pekerjaan Umum No.11 A/PRT/M/2006 Lampiran 2) dengan dua Kawasan Andalan sebagai berikut:

a. Kawasan Andalan Perkotaan Jakarta (Metropolitan Jakarta).

b. Kawasan Andalan Bogor-PuncakCianjur (Bopunjur).

c. Sistem Jaringan Prasarana Wilayah

Mengacu pada RTRW Nasional, RTRW Pulau Jawa dan Bali, juga RTRW Provinsi rencana sistem jaringan prasarana wilayah yang dikembangkan dalam Wilayah Sungai 2 Ci melingkupi: 
a. Jaringan Transportasi Darat; Jalan tol: Jakarta-Merak, Jakarta-CikampekBandung dan Jakarta-Bogor.

b. Jalan Kereta Api; Jakarta-Merak, JakartaBogor, Jakarta-Cikampek-Bandung dan Jakarta-Cikampek-Cirebon

c. Pelabuhan laut; Pelabuhan Internasional Tanjung Periuk (Jakarta).

d. Bandar Udara; Bandar udara skala internasional (Bandar udara SukarnoHatta).

Sistem Jaringan Sumber Daya Air; Prasarana dan sarana sumber daya air di Wilayah Sungai $2 \mathrm{Ci}$ terkait dengan dua Wilayah Sungai lainnya, yaitu Wilayah Sungai Cidanau-Ciujung-Cidurian (3 Ci) dan Wilayah Sungai Citarum (1 Ci). Dari kedua Wilayah Sungai inilah pasokan air bersih Jakarta berasal.

\subsection{Arahan Pengembangan Kawasan dan Pusat Kegiatan}

Berdasarkan pola kepadatan penduduk yang bermukim di Wilayah Sungai $2 \mathrm{Ci}$ terlihat pengelompokan penduduk terjadi pada kawasan perkotaan Jabodetabekpunjur (Kawasan Metropolitan Jabodetabekpunjur).

Arahan Pola Pemanfaatan Ruang (Pola Ruang)

Berdasarkan pemetaan RTRW Pulau Jawa dan Bali, juga RTRW Provinsi (Banten, DKI Jakarta dan Jawa Barat), dilihat dari
Rencana Pola Ruang, pada akhir tahun 2030, rencana penggunaan ruang di Wilayah Sungai $2 \mathrm{Ci}$ akan didominasi oleh kawasan permukiman/ perkotaan.

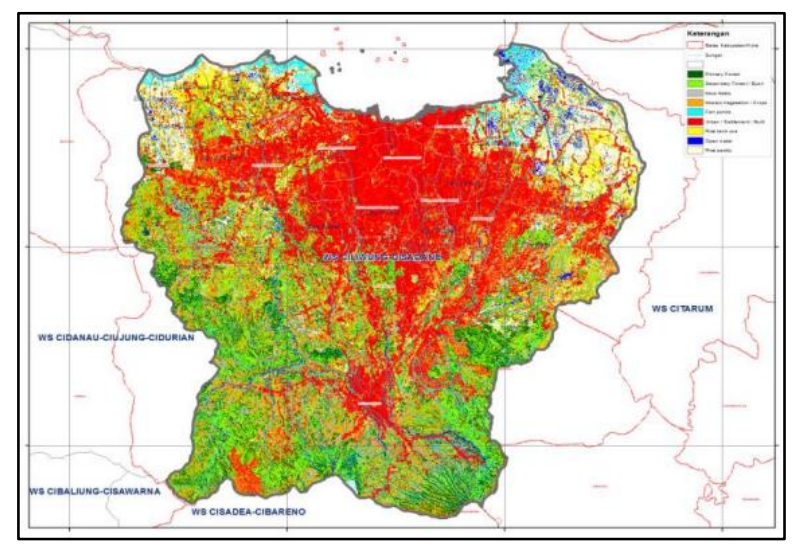

Gambar 1. Peta tata guna lahan wilayah $2 \mathrm{Ci}$ Sumber: Pola Pengelolaan Sumber Daya Air Wilayah Sungai Ciliwung-Cisadane 2015

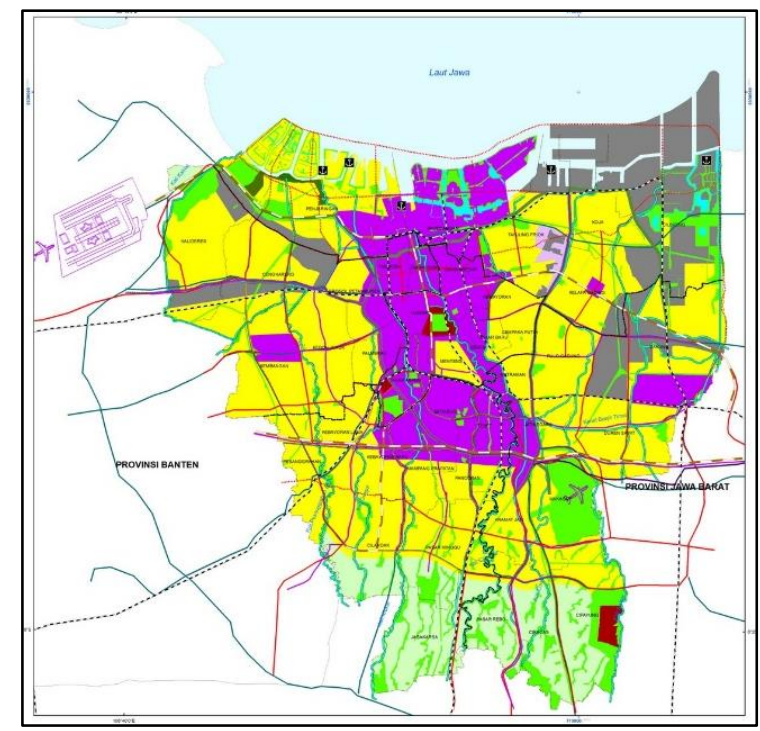

Gambar 2. Peta Rencana Tata Ruang Wilayah Provinsi Jakarta 2011-2030 Sumber: Pemprov DKI Jakarta

\section{ANALISIS DATA}

\subsection{Daerah Aliran Sungai}


Jakarta terletak pada daerah pengaliran dua sungai besar di wilayah barat Jawa, yaitu sungai Ciliwung dan sungai Cisadane (2 Ci). Karena itu, wajar bila dinyatakan pengelolaan sumber daya air Jakarta dipengaruhi oleh kedua sungai ini. Karena itu, pengelolaan air Jakarta tidak akan terlepas dari pengelolaan alam wilayah Bogor, Depok, Tangerang, Bekasi, Puncak dan Cianjur sebagai satu kesatuan wilayah Metropolitan Jabodetabekpunjur.

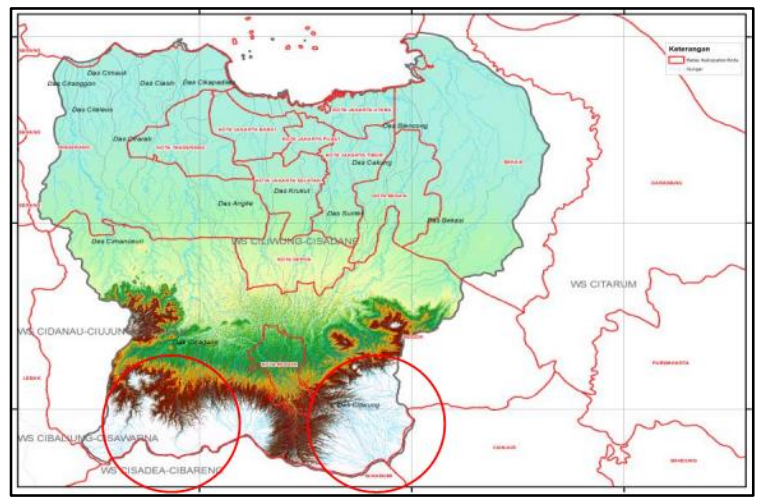

Gambar 3. Peta topografi wilayah $2 \mathrm{Ci}$

Sumber: Pola Pengelolaan Sumber Daya Air Wilayah Sungai Ciliwung-Cisadane 2015

Kondisi Daerah Aliran Sungai CiliwungCisadane terdiri dari $30 \%$ wilayah landai dengan elevasi antara 0 hingga 100 meter dari permukaan laut. $70 \%$ sisanya merupakan wilayah dataran tinggi dengan elevasi antara 100 hingga 2000 meter dari permukaan laut. Wilayah utara kawasan Daerah Aliran Sungai ini adalah dataran rendah yang mengalir ke Laut Jawa, sehingga air mengalir ke Utara dan bermuara di Laut Jawa. Seperti terlihat pada peta, Jakarta berada pada wilayah Utara yang bersifat landai, dengan tiga belas sungai yang berasal dari Sungai Ciliwung dan Sungai Cisadane bermuara di Pantai Jakarta.

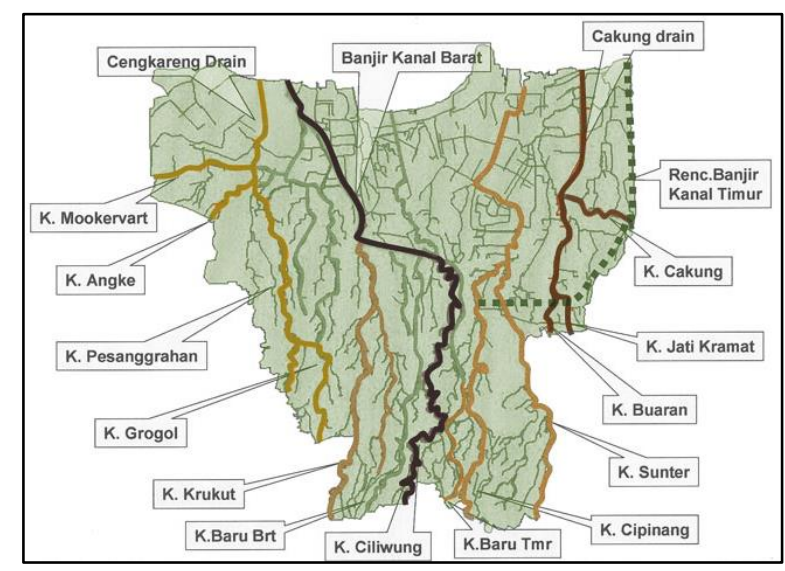

Gambar 4. Peta Tiga Belas Sungai Jakarta Sumber: www.serverjakarta.com

Ciliwung memiliki Daerah Pengaliran seluas 34.700 Ha, dengan panjang 117 Km. Daerah Pengaliran ini dibagi menjadi tiga bagian; bagian hilir, bagian tengah, dan bagian hulu. Bagian hilir mencakup bagian sungai Ciliwung dari muaranya di hilir sampai Pintu Air Manggarai, lalu masuk ke Saluran Kanal Barat. Wilayah Jakarta yang dilintasi bagian hilir Ciliwung ini mencakup Jakarta Utara, Jakarta Barat, Jakarta Pusat, dan Jakarta Selatan.

Bagian tengah Sungai Ciliwung melintasi Kota Depok, Kota Bogor, dan Kabupaten Bogor (Sukaraja, Cibinong, Bojonggede, Cimanggis). Bagian hulu Sungai Ciliwung mencakup sebagian besar wilayah Kabupaten Bogor (Ciawi, Megamendung, 
Cisarua, Sukaraja) dan sebagian kecil Kota Bogor (Bogor Timur).

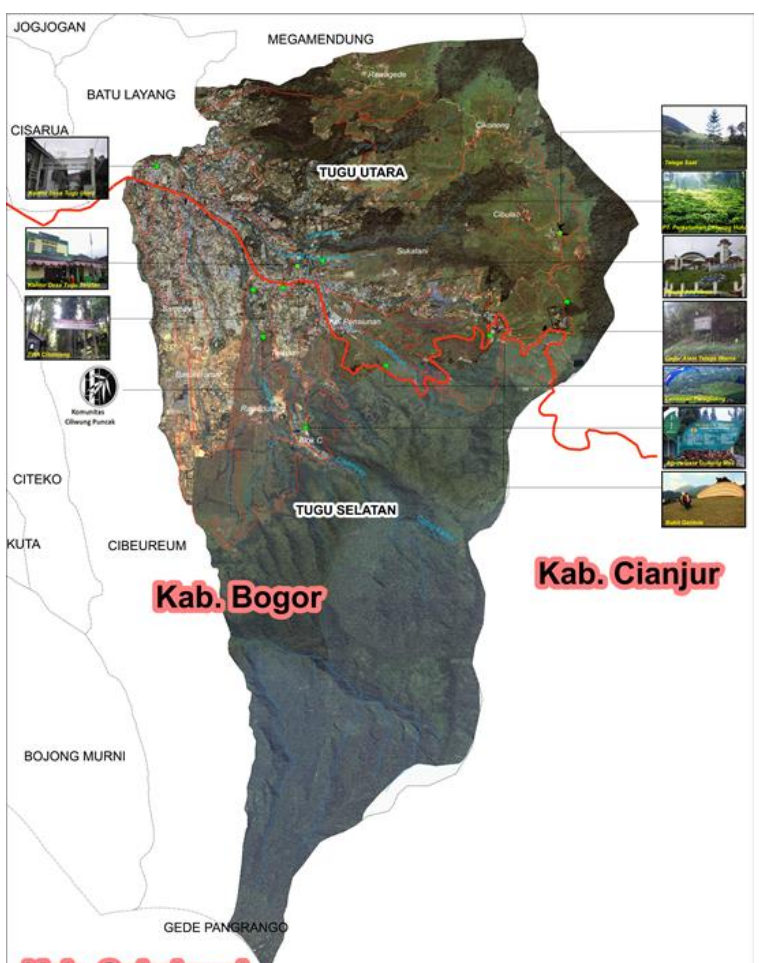

Kab.Sukabumi

Gambar 5. Peta Kawasan Puncak

Sumber: Forest Watch Indonesia (2012)

Kawasan Puncak di Kabupaten Bogor merupakan sebuah Kawasan yang memegang peranan vital bagi aliran sungai yang mengalir menuju Pantai Utara Jawa yang melintasi wilayah Jakarta. Peranan vital ini disebabkan karena seluruh kawasan Puncak merupakan bagian hulu dari Daerah Aliran Sungai dari empat sungai besar yang dua di antaranya melintasi Jakarta, yaitu Ciliwung dan Cisadane. Selain itu, fungsi vital ini disebabkan oleh fungsinya sebagai penyedia air utama untuk tiga Daerah Aliran Sungai, yaitu sungai Ciliwung, Bekasi dan Citarum. Karena itu bisa dikatakan kondisi kawasan Puncak akan memberikan dampak langsung pada Sungai Ciliwung yang melintasi Jakarta.

Menurut data yang didapat dari Forest Watch Indonesia, terjadi pengurangan luas tutupan lahan berupa hutan (deforestasi) di Propinsi Jawa Barat. Besar pengurangan yang terukur sejak tahun 2000 hingga tahun 2009 mencapai $16,2 \%$ atau setara dengan luasan 599,42 Ha. Pada tahun 2009, luas tutupan hutan yang tersisa sebesar $9,7 \%$ atau setara dengan luasan 358, $304 \mathrm{Ha}$ untuk mendukung wilayah Jawa Barat yang memiliki luas 3,7 juta Ha.

Meninjau kembali Undang-Undang Nomor 41 tahun 1999 tentang Kehutanan, pasal 3, 6, dan 18; Dinyatakan bahwa keberadaan kawasan hutan yang optimal mempunyai luasan yang cukup dan sebaran proporsional minimal 30\% dari luas DAS atau pulau. Hal ini ditegaskan kembali pada UndangUndang Nomor 26 tahun 2007 tentang Penataan Ruang. Undang-undang ini menyatakan bahwa luasan dari kawasan hutan dalam suatu tata ruang wilayah paling sedikit 30\% dari Daerah Aliran Sungai (DAS). Melihat perundang-undangan yang berlaku, luasan hutan yang tersisa tidak akan bisa optimal mendukung keseimbangan tata guna air Jawa Barat.

Karena itu, pada tahun 2010, dikeluarkan Peraturan Daerah Propinsi Jawa Barat 
Nomor 22 tahun 2010 tentang Rencana Tata Ruang Wilayah Propinsi. Pada Peraturan Daerah ini, pasal 26 menetapkan luasan sebesar $45 \%$ dari wilayahnya untuk menjadi kawasan lindung pada 2018 dan menetapkan luasan minimum hutan sebesar $30 \%$ untuk setiap Daerah Aliran Sungai.

Namun begitu, pada periode 2000 hingga 2009, pada wilayah administrasi kabupaten
Bogor, didapati kehilangan tutupan hutan telah mencapai $24,6 \%$ atau setara dengan 73,591 Ha dengan menyisakan luas tutupan hutan sebesar 13,7\%, atau setara dengan 40,991 Ha. Jumlah ini tentunya tidak sesuai dengan peraturan yang disebutkan sebelumnya yang menyaratkan luas tutupan hutan sebesar $30 \%$.

\begin{tabular}{|l|r|r|r|r|}
\hline \multicolumn{1}{|c|}{ Kondisi Hutan 2000 - 2009 } & KSA/PA (Ha) & HP (Ha) & APL (Ha) & Jumlah (Ha) \\
\hline Kehilangan Hutan & 0.05 & $2,346.71$ & $2,411.27$ & $4,758.03$ \\
\hline Tetap Bukan Hutan & 0.00 & 115.64 & 114.53 & 230.17 \\
\hline Tetap Hutan & 0.02 & $1,451.17$ & $2,125.01$ & $3,576.20$ \\
\hline Total & 0.07 & $3,913.52$ & $4,650.81$ & $8,564.40$ \\
\hline
\end{tabular}

Tabel 1. Data kondisi hutan lindung kawasan Puncak

Sumber: Forest Watch Indonesia (2012)

\begin{tabular}{|l|r|r|r|r|r|r|}
\hline Kabupaten/ Kota & $\begin{array}{c}\text { Kehilangan } \\
\text { Hutan (Ha) }\end{array}$ & $\begin{array}{c}\text { Tetap } \\
\text { Bukan }\end{array}$ & $\begin{array}{c}\text { Tetap } \\
\text { Hutan (Ha) }\end{array}$ & \multicolumn{1}{c|}{$\begin{array}{c}\text { Luas } \\
\text { Wilayah }\end{array}$} & $\begin{array}{c}\text { \% Tutupan } \\
\text { Lahan }\end{array}$ & $\begin{array}{c}\text { \% } \\
\text { Kehilangan }\end{array}$ \\
\hline Kota Depok & & $19,789.12$ & & $19,789.12$ & 0.00 & 0.00 \\
\hline Bogor & $73,591.46$ & $184,577.52$ & $40,991.06$ & $299,160.04$ & 13.70 & 24.60 \\
\hline Kota Bogor & & $11,249.08$ & & $11,249.08$ & 0.00 & 0.00 \\
\hline Bekasi & 90.18 & $131,512.67$ & & $131,602.85$ & 0.00 & 0.07 \\
\hline Kerawang & $18,066.47$ & $169,078.59$ & $4,261.74$ & $191,406.80$ & 2.23 & 9.44 \\
\hline Cianjur & $64,112.27$ & $250,500.23$ & $44,386.59$ & $358,999.09$ & 12.36 & 17.86 \\
\hline Purwakarta & $40,068.88$ & $44,339.75$ & $7,553.21$ & $91,961.84$ & 8.21 & 43.57 \\
\hline Sukabumi & $56,006.78$ & $325,725.47$ & $34,086.89$ & $415,819.14$ & 8.20 & 13.47 \\
\hline Kota Sukabumi & 0.53 & $4,868.60$ & & $4,869.13$ & 0.00 & 0.01 \\
\hline
\end{tabular}

Tabel 2. Kondisi tutupan hutan di wilayah Kabupaten Bogor dan sekitarnya

Sumber: Forest Watch Indonesia (2012)

Kehilangan tutupan hutan di wilayah

Kabupaten Bogor ini adalah masalah yang serius. Sebagai wilayah penyangga Daerah Khusus Ibukota Jakarta, Bogor adalah pelindung Jakarta ditinjau dari sisi ekologi. Dengan hilangnya luas tutupan hutan wilayah Bogor, jumlah limpasan permukaan dari hujan yang turun di Bogor akan menjadi lebih besar dan dialirkan dengan cepat menuju Jakarta melalui sungai Ciliwung yang berhulu di Puncak, Kabupaten Bogor. Permasalahan air bawah tanahpun tidak 
akan terelakkan. Dengan berkurangnya tutupan hutan,

maka infiltrasi air ke dalam tanah akan menjadi lebih rendah, yang mengakibatkan laju input air bawah tanah juga menjadi rendah. Rendahnya input air bawah tanah ini akan mempercepat laju intrusi air laut ke daratan. Pada gilirannya nanti, hal ini akan menurunkan permukaan tanah (land subsidence). Penurunan permukaan tanah ini akan memperburuk kondisi banjir Jakarta.
Dari pengukuran area tutupan hutan untuk enam Daerah Aliran Sungai di Kabupaten Bogor yang mengalir melintasi Jakarta, hanya Daerah Aliran Sungai Ciliwung yang memiliki tutupan hutan. Walaupun begitu, luas daerah tutupan hutan tersebut hanya mencapai $12,22 \%$ atau seluas 3,565 Ha. Bila dihitung, dari persentase luasan total DAS yang melintasi Jakarta, hanya tersedia daerah hutan sebesar $4,30 \%$.

\begin{tabular}{|l|r|r|r|r|}
\hline \multicolumn{1}{|c|}{ Daerah Aliran Sungai } & \multicolumn{1}{c|}{$\begin{array}{c}\text { 2009: } \\
\text { Tutupan } \\
\text { Hutan }(\mathrm{Ha})\end{array}$} & $\begin{array}{c}\text { 2009: } \\
\text { Bukan } \\
\text { Tutupan }\end{array}$ & $\begin{array}{c}\text { Luas DAS } \\
\text { di } \\
\text { Kabupaten }\end{array}$ & $\begin{array}{c}\text { \% Tutupan } \\
\text { Hutan }\end{array}$ \\
\hline Ciliwung & $3,565.61$ & $25,620.93$ & $29,186.54$ & 12.22 \\
\hline Kali Angke Pesanggrahan & & $35,526.08$ & $35,526.08$ & 0.00 \\
\hline Kali Buaran & & $1,544.53$ & $1,544.53$ & 0.00 \\
\hline Kali Cakung & & $7,379.33$ & $7,379.33$ & 0.00 \\
\hline Kali Krukut & & $5,048.21$ & $5,048.21$ & 0.00 \\
\hline Kali Sunter & & $4,227.56$ & $4,227.56$ & 0.00 \\
\hline Total & $3,565.61$ & $79,346.64$ & $82,912.25$ & 4.30 \\
\hline
\end{tabular}

Tabel 3. Kondisi Daerah Aliran Sungai yang berasal dari Bogor menuju Jakarta Sumber: Forest Watch Indonesia (2012)

Menurut Eko Sularto (2006) dalam dengan mengembalikan fungsi hutan dari penelitiannya pada DAS Ciliwung Hulu, tegalan dan pemukiman yang ada.

simulasi penambahan luasan hutan dari $33,5 \%$ menjadi $35 \%$ belum mampu menurunkan debit banjir, hanya menurunkan debit dan volume aliran. Namun, debit banjir dapat diminimalkan dengan adanya penambahan luas hutan menjadi $40 \%$ luas DAS yang ada. Penambahan ini dilakukan

Namun begitu, penambahan luas lahan terbangun sebagai pemukiman dan tegalan dari angka 19,5\% menjadi 25\% luas DAS yang ada sudah bisa meningkatkan debit banjir dan debit aliran yang melalui sungai Ciliwung. Dari pernyataan ini, bisa dikatakan pengubahan lahan hijau tidak 
terbangun menjadi lahan terbangun memberi pengaruh lebih besar daripada pengubahan lahan terbangun menjadi lahan hijau.
Perubahan tata guna lahan di Daerah Aliran Sungai Ciliwung yang telah terjadi sejak tahun 1970 hingga tahun 2000 dapat dilihat dari tabel berikut.

\begin{tabular}{|c|c|c|c|c|c|c|c|c|}
\hline \multirow[b]{2}{*}{ Land Use } & \multicolumn{2}{|c|}{1970} & \multicolumn{2}{|c|}{1980} & \multicolumn{2}{|c|}{1990} & \multicolumn{2}{|c|}{2000} \\
\hline & $\mathrm{Ha}$ & \begin{tabular}{|c|}
$\%$ area of \\
river basin
\end{tabular} & $\mathrm{Ha}$ & $\begin{array}{c}\% \text { area of } \\
\text { river basin }\end{array}$ & $\mathrm{Ha}$ & \begin{tabular}{|c|}
$\%$ area of \\
river basin
\end{tabular} & $\mathrm{Ha}$ & $\begin{array}{c}\% \text { area of } \\
\text { river basin }\end{array}$ \\
\hline \multicolumn{9}{|l|}{ Undeveloped Area } \\
\hline Land for Farming and Green Open Space & $15,312.13$ & 39.55 & $13,817.70$ & 35.69 & $13,066.61$ & 33.75 & $10,478.55$ & 27.07 \\
\hline Wet Land and Water Body & $10,375.86$ & 26.80 & $8,656.87$ & 22.36 & $5,222.77$ & 13.49 & $4,601.29$ & 11.88 \\
\hline Sub Total & $25,687.99$ & 66.35 & $22,474.57$ & 58.05 & $18,289.38$ & 47.24 & $15,079.84$ & 38.95 \\
\hline \multicolumn{9}{|l|}{ Developed Area } \\
\hline Settlement & $12,060.00$ & 31.15 & $12,385.21$ & 31.99 & $13,984.18$ & 36.12 & $14,410.05$ & 37.22 \\
\hline Industry & 193.58 & 0.50 & $1,711.24$ & 4.42 & $2,470.07$ & 6.38 & $3,883.20$ & 10.03 \\
\hline Business Services & 774.32 & 2.00 & $2,144.86$ & 5.54 & $3,972.25$ & 10.26 & $5,342.79$ & 13.80 \\
\hline Sub Total & $13,027.90$ & 33.65 & $16,241.31$ & 41.95 & $20,426.50$ & 52.76 & $23,636.04$ & 61.05 \\
\hline Total & $38,715.89$ & 100.00 & $38,715.88$ & 100.00 & $38,715.88$ & 100.00 & $38,715.88$ & 100.00 \\
\hline
\end{tabular}

Tabel 4. Perubahan tata guna lahan pada DAS Ciliwung $1970-2000$

Sumber: Melati F. Fachrul (2007)

Pada tabel di atas, terlihat perubahan luas lahan belum terbangun menjadi lahan terbangun dalam kurun waktu 30 tahun. Penurunan luasan yang terjadi luar biasa besar, dari 66,35\% luasan keseluruhan DAS menjadi hanya $38,95 \%$ saja. Sedangkan luasan wilayah terbangun naik, dari 33,65\% menjadi $61,05 \%$.

Selama kurun waktu 1980 hingga 1990, pembangunan besar-besaran pemukiman di wilayah Jakarta Selatan dan Depok terjadi. Selama kurun waktu ini, terjadi konversi besar-besaran yang menurunkan luasan lahan hijau dan lahan basah. Pada kurun waktu 1990 hingga 2000, konversi lahan hijau menjadi pemukiman ini meluas ke wilayah Bogor dan Ciawi.

Perkembangan area bisnis dan industri terjadi di bagian hilir Daerah Aliran Sungai Ciliwung sejak tahun 1970 hingga tahun
2000. Perkembangan di wilayah hilir ini merupakan efek dari pengembangan Jakarta sebagai Ibu Kota. Dari tabel diperoleh informasi bahwa laju pengembangan luas lahan industri jauh lebih besar dari pengembangan lahan untuk keperluan area bisnis. Laju pengembangan perumahan memiliki besaran yang paling kecil di antara dua parameter lainnya. Pengembangan perumahan, seperti disebutkan dalam Master Plan Jakarta tahun 1985 hingga 2005, dikembangkan menuju bagian timur Jakarta; Bekasi, dan bagian barat Jakarta; Tangerang. Temuan Eko Sularto (2006) dikuatkan oleh penelitian Simatupang (2007) yang menyatakan penyebab utama banjir di Daerah Aliran Sungai Ciliwung bukan berasal dari peningkatan curah hujan, karena terdapat kondisi penurunan curah hujan, namun debit aliran sungai tetap meningkat. 
Terdapat hubungan positif antara tata guna lahan dan debit aliran sebesar 13\%. Hal ini berarti perubahan yang terjadi pada tata guna lahan akan berdampak pada perubahan besar debit alir yang dihasilkan.

Dalam penelitiannya juga, Simatupang menyatakan terdapat hubungan antara penggunaan lahan bantaran sungai dengan naiknya elevasi muka air. Korelasi hubungan antara penggunaan lahan bantaran sungai dengan naiknya elevasi muka air bernilai 96,29\%. Penggunaan lahan bantaran sungai sebagai pemukiman liar telah menyebabkan berkurangnya lahan larian air, yang berakibat pada usaha air untuk menyesuaikan dengan debitnya malah menaikkan elevasi air. Hal ini tergambar dari naiknya elevasi air pada pintu Manggarai dari tahun 1996 setinggi $970 \mathrm{~cm}$, menjadi $1050 \mathrm{~cm}$ pada tahun 2002, dan 1061 pada tahun 2007. Dalam rentang waktu antara 1996 sampai 2007, elevasi air di Katulampa telah naik $16,8 \mathrm{~cm}$, di Depok naik setinggi $56,9 \mathrm{~cm}$, dan di Manggarai kenaikan terukur setinggi $91 \mathrm{~cm}$.

Disebutkan, pada tahun 2008, bantaran Sungai Ciliwung yang telah digunakan sebagai pemukiman liar telah mencapai luasan 13,77 $\mathrm{Ha}$, atau setara dengan $8 \%$ dari total luasan bantaran Sungai Ciliwung. Di Manggarai, nilai luasan bantaran sungai yang telah digunakan sebagai lahan pemukiman liar telah mencapai 9,317 Ha.
Permasalahan pemukiman liar ini sendiri terus menerus berulang karena setelah direlokasi, pemukiman-pemukiman liar tersebut kembali didirikan setelah beberapa waktu. Alasan-alasan seperti penggantian kerugian finansial untuk relokasi ke wilayah baru yang tidak mencukupi menjadi salah satu penyebab kembalinya warga yang telah direlokasi ke bantaran sungai. Alasan lainnya adalah sebagian besar penghuni bantaran sungai adalah orang-orang yang tidak memiliki pekerjaan tetap, sehingga mereka kesulitan untuk mendirikan bangunan baru, atau untuk menyewa rumah/ rumah susun. Permasalahan lainnya datang dari wilayah relokasi sendiri. Terkadang, untuk relokasi telah disediakan sebuah fasilitas khusus berupa rumah susun. Namun, terkadang, fasilitas penunjang (listrik, air) di rumah susun tersebut tidak berfungsi, yang menyebabkan menurunnya tingkat kenyamanan dan sanitasi fasilitas tersebut.

\subsection{Kondisi Air Tanah}

Dalam berkas Pola Pengelolaan Sumber Daya Air Wilayah Sungai Ciliwung Cisadane, dinyatakan ketersediaan air tanah di Wilayah Sungai 2 Ci adalah sebesar 1.899 juta $\mathrm{m}^{3} /$ tahun. Namun data aktual pengambilan tersebut masih terbatas. Walaupun telah diberlakukan peraturan dan perizinan untuk dapat melakukan pengambilan air tanah, baik air tanah 
dangkal maupun air tanah dalam, belum bisa dikatakan data pengambilan air bawah tanah yang terdaftar merupakan data pengambilan yang sebenarnya terjadi di lapangan. Pengambilan air tanah yang terjadi di lapangan setidaknya diperkirakan tiga kali lebih besar dibandingkan dengan pengambilan air tanah yang memang terdaftar dengan benar.

\begin{tabular}{|l|r|r|r|r|r|r|}
\hline $\begin{array}{c}\text { Cekungan Air } \\
\text { Tanah (CAT) }\end{array}$ & $\begin{array}{c}\text { Area } \\
(\mathrm{km} 2)\end{array}$ & $\begin{array}{c}\text { Potensi Air } \\
\text { Tanah }\end{array}$ & $\begin{array}{c}\text { Abstraksi } \\
\text { Air Tanah }\end{array}$ & $\begin{array}{c}\text { Neraca Air } \\
\text { Tanah }\end{array}$ & Catatan & $\begin{array}{c}\text { Persentase } \\
\text { Abstraksi } \\
\text { Air Tanah }\end{array}$ \\
\hline juta m3/th & juta m3/th & juta m3/th & & 47 \\
\hline CAT Jakarta & 1439 & 40 & 19 & 21 & + & 130 \\
\hline CAT Bogor & 1311 & 37 & 48 & 11 & - & 83 \\
\hline Total $2 \mathrm{Ci}$ & 2750 & 77 & 67 & 10 & & (10 \\
\hline
\end{tabular}

Tabel 5. Perkiraan pengambilan air tanah wilayah $2 \mathrm{Ci}$

Sumber: Pola Pengelolaan Sumber Daya Air Wilayah Sungai Ciliwung-Cisadane 2015

Dari tabel perkiraan pengambilan air tanah di atas, terlihat perkiraan pengambilan air tanah yang terjadi pada Daerah Aliran Sungai 2 Ci (Ciliwung - Cisadane) telah mencapai $87 \%$. Dengan kondisi hutan yang berfungsi sebagai tempat penyimpanan air dan pengisian air tanah semakin berkurang, diperkirakan, debit air tanah akan semakin berkurang.

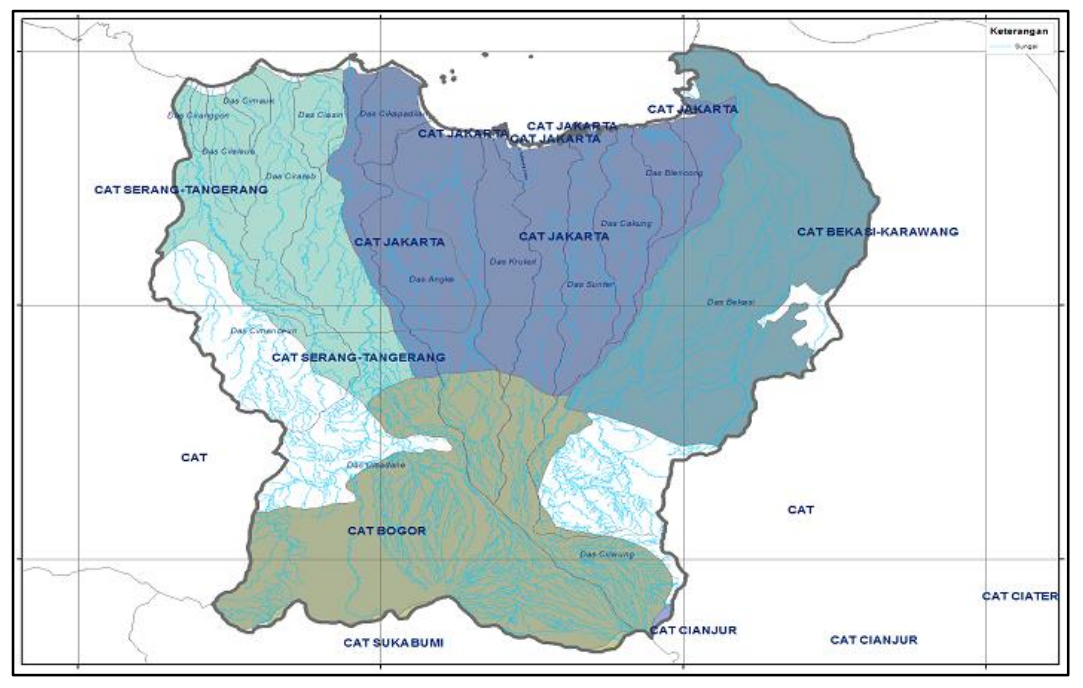

Gambar 6. Peta Cekungan Air Tanah Jakarta dan sekitarnya

Sumber: Pola Pengelolaan Sumber Daya Air Wilayah Sungai Ciliwung-Cisadane 2015
Dengan kekosongan air tanah, akan timbul permasalahan masuknya air laut mengisi kekosongan yang ditinggalkan air tanah, sehingga intrusi air laut akan masuk lebih jauh lagi menuju daratan. Intrusi air laut ini akan membahayakan keberadaan Jakarta dan meningkatkan laju penurunan tanah. 


\subsection{Demografi}

Berdasarkan data pada Keputusan Menteri Pekerjaan Umum dan Perumahan Rakyat Nomor 26/KPTS/M/2015 tentang pola pengelolaan sumber daya air wilayah Sungai Ciliwung-Cisadane 2015, pendataan potensi desa tahun 2008 yang diproyeksikan ke tahun 2010, jumlah penduduk di Wilayah
Sungai Ciliwung - Cisadane berjumlah sebanyak 25.014.192 jiwa yang terdiri dari 12.735.189 Kepala Keluarga (KK), dengan rata-rata pertumbuhan penduduk di Wilayah Sungai Ciliwung - Cisadane selama sepuluh tahun terakhir adalah sebesar $1,4 \%$ dengan pertumbuhan terkecil berada di Jakarta Pusat $(-3,8 \%)$.

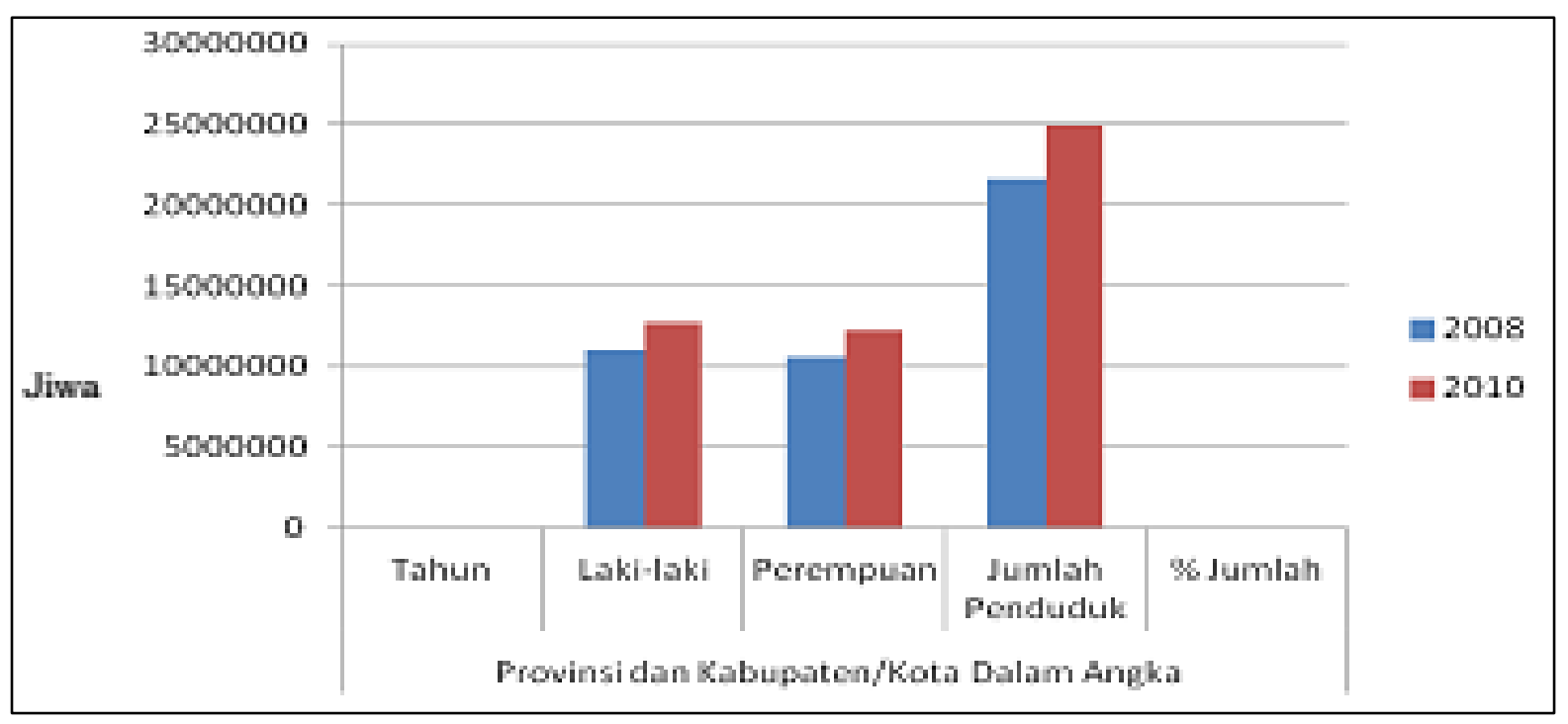

Gambar 7. Data penduduk wilayah $2 \mathrm{Ci}$

Sumber: Pola Pengelolaan Sumber Daya Air Wilayah Sungai Ciliwung-Cisadane 2015 
Pertumbuhan penduduk ini didukung juga oleh laju urbanisasi yang terjadi menuju area Jakarta dan sekitarnya. Menurut pemaparan Wouter de Hamer pada acara diskusi dengan tajuk "Menata Air Menjelang Kehidupan Penuh Vitalitas" di Universitas Pembangunan Jaya, akan terjadi peningkatan area perkotaan sebesar $100 \%$ pada tahun 2030, sejak diproyeksikan dari tahun besaran tahun 2010. Perluasan ini akan memicu kekurangan air untuk wilayah-wilayah yang mengalami pemekaran dan memicu kenaikan debit aliran permukaan.

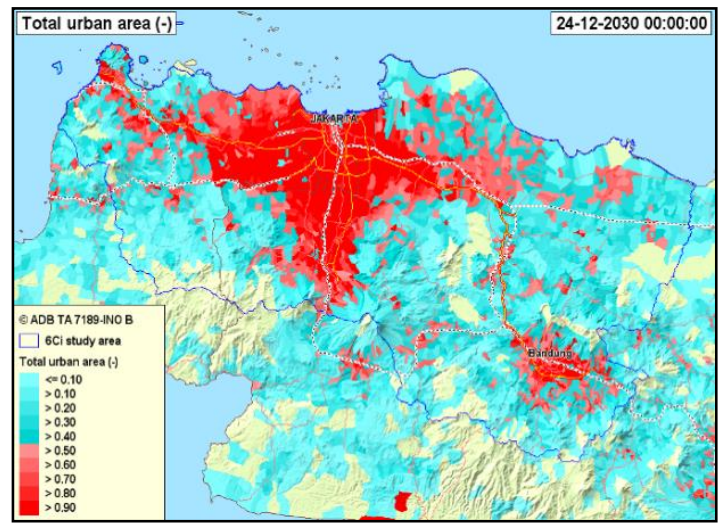

Gambar 8. Proyeksi Pemekaran Perkotaan tahun 2030

Sumber: Wouter de Hamer (2013)

\subsection{Kualitas Air}

Pada penelitian yang dilakukan oleh Melati F Fachrul terdapat hubungan antara perubahan tata guna lahan Daerah Aliran Sungai Ciliwung terhadap nilai indeks kualitas air Sungai Ciliwung.

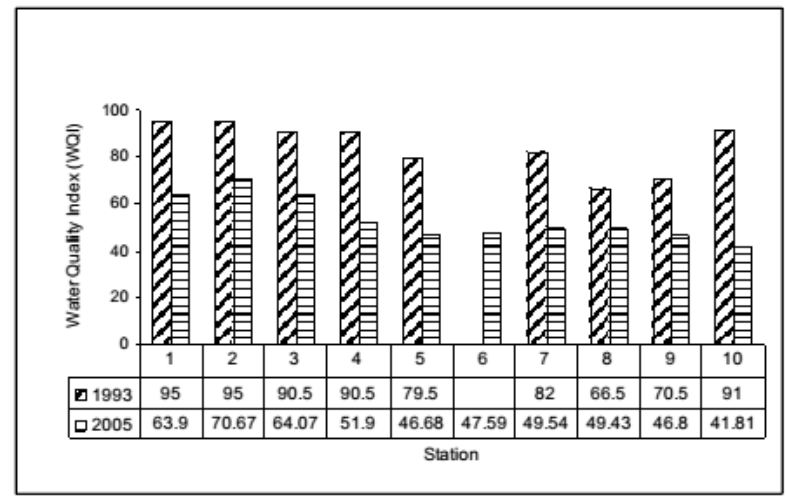

Gambar 9. Grafik Perbandingan Index Kualitas Air

Sumber: Melati F. Fachrul (2007)

Grafik di atas menunjukkan perubahan nilai Index Kualitas Air di Sungai Ciliwung yang diukur di 10 stasiun pengukuran pada kurun waktu 12 tahun, dari tahun 1993 sampai 2005. Terlihat nilai Index Kualitas Air pada tahun 1993 lebih tinggi dari tahun 2005 yang menunjukkan adanya penurunan nilai Index Kualitas Air. Rata-rata nilai Index Kualitas Air pada tahun 2005 adalah sebesar 33,38\%, yang menunjukkan kualitas air Sungai Ciliwung berada pada kondisi menengah menuju jelek.

Nilai kualitas air ini pula yang mendorong Jakarta untuk menjalankan program JEDI (Jakarta Emergency Dredging Initiative) pada tahun 2013. Tumpukan sampah yang terbawa arus sungai, ditambah depot sedimen yang terbawa dari hulu sungai menyebabkan pendangkalan dan penyempitan di sepanjang alur sungai. Pendangkalan ini menyebabkan naiknya 
elevasi air yang terkadang melebihi elevasi tanggul sungai, sehingga terjadi pelimpasan ketika debit banjir mengalir.

\subsection{Investasi}

Jakarta yang setiap tahunnya selalu mengalami ancaman banjir mengalami kerugian yang tidak sedikit. Menurut Firdaus Ali (2008), total kerugian yang diderita kota Jakarta karena banjir pada tahun 2007 saja mencapai 8,80 triliun rupiah. Bila dijumlahkan, total kerugian yang diderita Jakarta karena banjir besar yang terjadi pada tahun 2002, 2007, dan 2013 mencapai angka 38,7 triliun rupiah. Kerugian ini belum dijumlahkan dengan begitu banyaknya kerugian lain karena kerentanan air DKI Jakarta.

Untuk pemenuhan kebutuhan air baku saja, karena kelangkaan air baku untuk produksi air bersih perpipaan, pada tahun 2012, Jakarta telah mengalami defisit debit sekitar 12,185 L/detik. Jumlah ini baru bisa melayani $44 \%$ dari total kebutuhan air Jakarta. Belum lagi, karena tiga belas sungai yang melintasi Jakarta telah tercemar seluruhnya, air sungai Jakarta membutuhkan pengolahan yang tidak sedikit harganya bila ingin dimanfaatkan. Pada tahun 2013, Anggaran Pengelolaan Lingkungan Hidup yang dianggarkan dalam APBD DKI Jakarta baru mencapai angka 24,9 miliar rupiah (BPLHD, 2013), sedangkan total kerugian banjir Jakarta pada tahun itu telah mencapai 20 triliun rupiah.

Melihat kenyataan ini, sudah saatnya pembangunan yang dilaksanakan memiliki landasan lingkungan yang kuat. Sudah waktunya investasi lingkungan ditingkatkan. Nilai anggaran pengelolaan lingkungan ini mungkin akan bernilai sangat besar pada awalnya, tetapi akan menyelamatkan anggaran pada sisi yang lain. Pada lembar fakta yang dikeluarkan oleh Center for International Forestry Research (CIFOR) pada Juni 2013 disebutkan bahwa terdapat kisaran prakiraan nilai pengaturan dan pemasokan air. Secara global, didapat angka sebesar 2,3 triliun dollar AS. Nilai fungsi penyimpanan air hutan negara Cina diduga sebesar 7,5 triliun yuan, yang bernilai tiga kali lipat nilai kayu dari dalam hutannya. Studi keberadaan hutan di Gunung Kenya menyelamatkan perekonomian negara tersebut sebesar lebih dari 20 juta dollar AS karena melindungi dua sistem sungai utama Kenya; Sungai Tana dan Sungai Ewaso Ngiro.

\section{KESIMPULAN}

Permasalahan Konservasi Air Daerah Khusus Ibukota Jakarta tidak bisa dilpandang sebagai permasalahan wilayah Jakarta sendiri. Penempatan Jakarta 
sebagai bagian hilir dari tiga belas sungai menyebabkan kota ini rentan terhadap bencana. Banjir yang mengintai setiap tahun tidak bisa diselesaikan hanya dengan membangun jaringan saluran drainase di mana-mana. Ditambah pertambahan penduduk yang menyebabkan meningkatnya permintaan akan lahan, baik untuk perumahan, maupun bisnis dan industri, permasalahan air Jakarta semakin bertambah. Berikut adalah permasalahanpermasalahan air yang timbul ditinjau dari sisi konservasi Sumber Daya Air.

Perubahan tata guna lahan terjadi setiap tahun menyebabkan semakin berkurangnya lahan hijau.

Pengurangan lahan hutan di hulu Daerah Aliran Sungai Ciliwung menyebabkan naiknya debit larian permukaan yang mengalir ke Jakarta.

Penurunan fungsi hutan dan peningkatan debit larian yang mengalir ke dalam sungai Ciliwung meningkatkan erosi lahan yang menyebabkan pertambahan kandungan sedimen dalam aliran sungai Ciliwung.

Peningkatan kandungan sedimen dalam aliran Sungai Ciliwung dan meningkatnya aktivitas di sekitar sungai menurunkan kualitas air Sungai Ciliwung

Peningkatan pengambilan air tanah menyebabkan kandungan air tanah menurun dan beresiko menyebabkan terjadinya intrusi air laut.

Penggunaan wilayah bantaran Sungai Ciliwung sebagai lokasi perumahan liar menyebabkan sulitnya upaya peremajaan sungai.

Investasi perbaikan dan pengembalian wilayah hulu dan bantaran Sungai Ciliwung dapat mengurangi kerugian yang diderita Kota Jakarta dari bencana banjir yang terjadi setiap tahunnya.

\section{Saran}

Dari hasil kajian yang telah dilakukan, masih perlu dilakukan verifikasi data primer terkait kebaruan permasalahan yang muncul.

Diperlukan kajian kebijakan dan pengecekan kinerja badan pembuat keputusan, terkait konservasi wilayah hijau, wilayah hutan, dan wilayah lindung.

Diperlukan pengecekan permasalahan konservasi pantai untuk melengkapi kajian konservasi air wilayah Jakarta.

\section{Daftar Pustaka}

1. Ali, Firdaus. 2008. Multi Purpose Deep Tunnel. Singapore International Water Week 
2. Anonym. 2005. Hutan dan Banjir; Tenggelam Dalam Suatu Fiksi Atau Berkembang Dalam Fakta. CIFOR

3. Anonym. 2007. Analisis Kawasan Lindung DAS Cisadane-AngkeCiliwung. Kementrian Negara Lingkungan Hidup

4. Anonym. 2012. Lembar Fakta; Hilangnya Fungsi Kawasan Lindung di Puncak Bogor. Forest Watch Indonesia

5. Anonym. 2012. Sistem dan Pola Pengendalian Banjir di Provinsi DKI Jakarta. Dinas Pekerjaan Umum Provinsi DKI Jakarta

6. Anonym. 2014. Potret Keadaan Hutan Indonesia 2009-2013, 2014, Forest Watch Indonesia

7. Anwar. 2011. Pengelolaan Sumber Daya Air Terpadu dan Berkelanjutan. Tapak

8. Brinkman. 2009. Jakarta Flood Hazard Mapping Framework. International Conference on Urban Flood Management

9. Caljouw, Mark. 2004. Flooding in Jakarta. The $1^{\text {st }}$ International Conference on Urban History

10. Fachrul, Melati Ferianita. 2007. Land Use and Water Quality Relationships in The Ciliwung River Basin Indonesia. International Congress River Basin Management
11. Hamer, Wouter de. 2013. Urban Water Management. Universitas Pembangunan Jaya

12. IRIDeS. 2013. Fact Finding Missions to Jakarta Report. Tohoku University

13. Keputusan Menteri Pekerjaan Umum dan Perumahan Rakyat Nomor 26/KPTS/M/2015, Pola Pengelolaan Sumber Daya Air Wilayah Sungai Ciliwung Cisadane

14. Nagel, P. Julius F. 2011. Pelestarian Hutan Dalam Hubungannya Dengan Lingkungan dan Potensi Ekonomi. PESAT: Universitas Gunadarma

15. Purwanto, Edi. 2004. Hubungan Antara Hutan dan Fungsi Daerah Aliran Sungai. Lokakarya World Agroforestry Centre

16. Pudjiharta, A. 2008. Pengaruh Pengelolaan Hutan Pada Hidrologi. Info Hutan

17. Simatupang, Maruli Tua Gregorius. 2009. Identification of Potential Effect of Illegal Residence in Floodplain and Socio-Economic Efforts For Solution. ICHARM

18. Sularto, Eko. 2006. Hubungan Penggunaan Lahan dan Kejadian Banjir Pada DAS Ciliwung Hulu Katulampa Menggunakan Model ANSWERS. Institut Pertanian Bogo 